\title{
Urgensi Asuransi Profesi Dalam Perkembangan Bisnis Di Indonesia
}

\author{
Muhammad Fikri Jauhari \\ Magister Kenotariatan Fakultas Hukum Universitas Airlangga \\ Email : Muhammadfikrijauhari@gmail.com
}

\begin{abstract}
Professional liability insurance (PLI), also called professional indemnity insurance (PII) but more commonly known as errors \& omissions $(\mathrm{E} \& \mathrm{O})$ in the US, is a form of liability insurance that helps protect professional advice- and service-providing individuals and companies from bearing the full cost of defending against a negligence claim made by a client, and damages awarded in such a civil lawsuit. The coverage focuses on alleged failure to perform on the part of, financial loss caused by, and error or omission in the service or product sold by the policyholder. These are potential causes for legal action that would not be covered by a more general liability insurance policy which addresses more direct forms of harm. Professional liability coverage sometimes also provides for the defense costs, including when legal action turns out to be groundless. Coverage does not include criminal prosecution, nor a wide range of potential liabilities under civil law that are not enumerated in the policy, but which may be subject to other forms of insurance. Professional liability insurance is required by law in some areas for certain kinds of professional practice (especially medical and legal), and is also sometimes required under contract by other businesses that are the beneficiaries of the advice or service.
\end{abstract}

Keyword: Professional Liability Insurance

\begin{abstract}
Abstrak
Asuransi pertanggung jawaban professional, juga disebut asuransi ganti rugi profesional namun lebih dikenal sebagai kesalahan \& kelalaian di Amerika Serikat, adalah bentuk asuransi yang berkewajiban untuk membantu melindungi terhadap seorang profesi dan memberikan layanan kepada individu dan perusahaan dari menanggung biaya penuh untuk mempertahankan diri dari tuntutan kelalaian yang dilakukan oleh klien, dan kerusakan diberikan dalam tuntutan perdata semacam itu. Cakupan ini berfokus pada dugaan kegagalan untuk melakukan pada bagian, kerugian finansial yang disebabkan oleh, dan kesalahan atau kelalaian dalam layanan atau produk yang dijual oleh pemegang polis. Ini
\end{abstract}


Fairness and Justice: Jurnal Ilmiah Ilmu Hukum

p-ISSN: 1858-0106 e-ISSN: 2502-3926

Volume X Nomor X Bulan, Tahun

http://jurnal.unmuhjember.ac.id/index.php/FA

adalah penyebab potensial untuk tindakan hukum yang tidak tercakup oleh polis asuransi kewajiban yang lebih umum yang menangani lebih banyak bentuk kerugian langsung. Cakupan tanggung jawab dari asuransi profesi terkadang juga menyediakan biaya untuk menanggung kerugian, termasuk saat tindakan hukum ternyata tidak beralasan. Dalam hal ini tidak termasuk penuntutan pidana, atau berbagai kewajiban potensial berdasarkan hukum perdata yang tidak disebutkan dalam polis, namun mungkin juga terkait dengan bentuk asuransi lainnya. Asuransi pertanggung jawaban profesi ini diwajibkan oleh hukum di beberapa bidang untuk jenis praktik profesional tertentu (khususnya medis dan hukum), dan kadang-kadang dibutuhkan berdasarkan kontrak oleh bisnis lain yang merupakan penerima manfaat dari nasehat atau layanan.

Keyword: Asuransi Profesi, Perlindungan Pekerjaan, Tangung Jawab

\section{Pendahuluan}

Setiap perbuatan manusia pasti menimbulkan suatu akibat (resiko) yang mengakibatkan keuntungan maupun kerugian. Kerugian yang muncul ini menjadi kekhawatiran atau ketakutan bagi tiap orang sehingga mereka merasa tidak aman apabila tidak memiliki kepastian bahwa ada orang lain yang bersama - sama mereka mau memikul penderitaan atau kerugian itu. Oleh karena manusia itu mencari jalan dan upaya agar resiko yang seharusnya ia tanggung sendiri itu dapat di kurangi dan di bagi kepada pihak lain yaitu dengan cara dibentuk perjanjian pelimpahan risiko dengan pihak lain. Perjanjian yang seperti itu dinamakan penanggungan atau perjanjian asuransi (verzekering) ${ }^{1}$,

Dalam kamus hukum sendiri risiko itu mempunyai arti kerugian atau bahaya, ${ }^{2}$ dalam kehidupan sehari hari memang perlu untuk dihindari, Emy Pangaribuan yang mengutip pendapat dari David L. Bichlehauptnmengemukakan bahwa ada beberapa cara yang dapat dilakukan kita sebagai manusia untuk mengatasi suatu risiko, antara lain :

${ }^{1}$ Sri Redjeki Hartono, Asuransi Dan Hukum Asuransi Di Indonesi, IKIP Semarang Press, 1985 hal 6-7

${ }^{2}$ Yan Pramadya Puspa, Kamus Hukum, Aneka Ilmu Semarang 1997, hal 740 Pengelola: Program Studi Ilmu Hukum Universitas Muhammadiyah Jember

Penerbit: Universitas Muhammadiyah Jember 
Fairness and Justice: Jurnal Ilmiah Ilmu Hukum

p-ISSN: 1858-0106 e-ISSN: 2502-3926

Volume X Nomor X Bulan, Tahun

http://jurnal.unmuhjember.ac.id/index.php/FA

1 Menghindari, menyingkir, atau menjauhi (avoidance) adalah suatu cara menghadapi risiko. Seseorang yang menjauh atau menghindar dari suatu pekerjaan, suatu benda yang penuh risiko, berarti dia berusaha menghindari risiko itu sendiri;

2 Mencegah (prevention). Dengan cara mencegah, suatu risiko mungkin akan teratasi sehingga beberapa akibat yang jelek yang tidak dikehendaki akan dapat dihindari;

3 Mengalihkan (transfer). Dengan model ini, yakni cara mengalihkan risiko dikandung pengertian bahwa seseorang yang menghadapi risiko meminta kepada orang lain untuk menerima risiko itu. Pengalihan risiko dilakukan dengan suatu perjanjian. Termasuk dalam pengertian dari asuransi; dan

4 Menerima (assumption or retention). Dengan model ini, berarti seseorang sudah pasrah saja terhadap risiko yang akan di tanggung. Hal ini bisa terjadi, karena bila sesuatu risiko yang dihadapi oleh seseorang diperkirakan tidak begitu besar atau jika usaha-usaha untuk menghindari, mencegah, mengalihkan diperhitungkan lebih besar keuntungannya maka orang akan menghadapi risiko tersebut. ${ }^{3}$

Dari apa yang di uraikan di atas, maka ada banyak sekali upaya untuk menanggulangi risiko yang mungkin akan terjadi, setiap individu mempunyai pilihan masing masing. Bagi pelaku usaha yang sudah berpengalaman dalam mengelola usahanya dan ataupun bagi para professional, terhadap risiko yang akan dihadapi dalam menjalankan aktivitas sehari hari, pada umumnya tidak dikelola sendiri akan tetapi dialihkan ke pihak lain, dalam hal ini ke lembaga asuransi.

Asuransi atau pertanggungan (Verzekering), di dalamnya tersirat pengertian adanya suatu risiko, yang terjadi belum dapat di pastikan, dan

${ }^{3}$ Sentoso sembiring, Hukum Asuransi, Nuansa Aulia 2014, hal 4 Pengelola: Program Studi Ilmu Hukum Universitas Muhammadiyah Jember

Penerbit: Universitas Muhammadiyah Jember 
Fairness and Justice: Jurnal Ilmiah Ilmu Hukum

p-ISSN: 1858-0106 e-ISSN: 2502-3926

Volume X Nomor X Bulan, Tahun

http://jurnal.unmuhjember.ac.id/index.php/FA

adanya pelimpahan tanggung jawab memikul beban risiko tersebut, kepada pihak lain yang sanggup mengambil alih tanggung jawab. Sebagai kontra prestasi dari pihak lain yang melimpahkan tanggung jawab ini, ia di wajibkan membayar sejumlah kepada pihak yang menerima pelimpahan tanggung jawab tersebut yang disebut premi.

Dari pengertian tersebut tampak bahwa asuransi mengambil peranan penting yaitu memberikan kepastian pembayaran kerugian yang di derita oleh si tertanggung atas kejadian yang tidak pasti.Selain itu dengan di adakannya perjanjian asuransi antara penanggung dengan tertanggung, maka secara tidak langsung melalui asuransi tersebut telah terjadi pengalihan risiko yang di timbulkan peristiwa tidak pasti dari pihak tertanggung kepada perusahaan asuransi sebagai pihak penanggung.

Menurut pasal 246 KUHD (Kitab Undang Undang Hukum Dagang) memberikan pengertian bahwa :

“Asuransi atau pertanggungan adalah suatu perjanjian, dengan mana seorang penanggung mengikatkan diri kepada seorang tertanggung dengan menerima suatu premi, untuk memberikan penggantian kepadanya karena suatu kerugian, kerusakan atau kehilangan keuntunngan yang di harapkan, yang mungkin akan di deritanya karena suatu peristiwa yang tak tertentu."

Adapun sifat-sifat yang terdapat pada pasal 246 KUHD yang berkaitan dengan perjanjian asuransi itu adalah :

1 Pada dasarnya adalah suatu perjanjian kerugian;

2 Asuransi adalah perjanjian bersyarat; dan

3 Asuransi adalah suatu perjanjian timbal balik. ${ }^{4}$

Pada hakikatnya karena asuransi itu adalah sebuah perjanjian, ketentuan ketentuan yang diutarakan diatas berlaku pula terhadapnya.

${ }^{4}$ Sri Redjeki Hartono, Op Cit hal 15

Pengelola: Program Studi Ilmu Hukum Universitas Muhammadiyah Jember

Penerbit: Universitas Muhammadiyah Jember 
Fairness and Justice: Jurnal Ilmiah Ilmu Hukum

p-ISSN: 1858-0106 e-ISSN: 2502-3926

Volume X Nomor X Bulan, Tahun

http://jurnal.unmuhjember.ac.id/index.php/FA

Memang, dengan mendasarkan pada ketentuan pasal 1 KUHD, pada dasarnya, ketentuan perikatan dan perjanjian yang terdapat dalam buku III BW dapat berlaku bagi perjanjian asuransi, selama ketentuan KUHD tidak mengatur. Asuransi pada dasarnya menjadi suatu perjanjian kerugian berarti bahwa penanggung mengikatkan diri untuk memberikan ganti kerugian kepada tertanggung yang seimbang dengan kerugian yang diderita tertanggung bersangkutan (prinsip idemnitas).Sedangkan asuransi sebagai perjanjian bersyarat (voorwaardelike overeenkomst) karena kewajiban penanggung untuk memberikan penggantian kepada tertanggung digantungkan kepada terjadinya peristiwa yang tidak diperjanjikan, apabila tidak terjadi, maka kewajiban penanggung pun tidak timbul, sebaliknya jika peristiwa terjadi namun tidak sesuai dengan yang disebutkan dalam perjanjian, penanggung juga tidak diwajibkan untuk memberi penggantian. Adapun perjanjian asuransi yang merupakan perjanjian timbal balik (wederkerige overeenkomst) karena hal ini disebabkan dalam perjanjian asuransi masing masing pihak mempunyai hak dan kewajiban yang saling berhadapan. ${ }^{5}$

Pada saat ini kebutuhan akan jasa perasuransian makin dirasakan, baik oleh perorangan maupun dunia usaha di Indonesia. Asuransi merupakan sarana financial dalam tata kehidupan, baik dalam menghadapi risiko yang mendasar seperti risiko kematian, atau dalam menghadapi risiko atas harta benda yang dimiliki.Demikian juga dalam dunia profesi, dalam menjalankan kegiatannya menghadapi berbagai risiko yang mungkin dapat mengganggu pekerjaannya.Walaupun banyak metode untuk menangani risiko, namun asuransi merupakan metode yang paling banyak di pakai.Asuransi menjanjikan perlindungan kepada

${ }^{5}$ Man Suparman Sastrawidjaja, Aspek aspek hukum asuransi dan surat berharga, ALUMNI, Bandung, 2003, hal 19

Pengelola: Program Studi Ilmu Hukum Universitas Muhammadiyah Jember

Penerbit: Universitas Muhammadiyah Jember 
Fairness and Justice: Jurnal Ilmiah Ilmu Hukum

p-ISSN: 1858-0106 e-ISSN: 2502-3926

Volume X Nomor X Bulan, Tahun

http://jurnal.unmuhjember.ac.id/index.php/FA

pihak tertanggung terhadap risiko yang dihadapi perorangan maupun risiko yang dihadapi perusahaan.

Seseorang dalam menjalankan profesinya tidak lepas dari berbuat salah, baik itu yang di sengaja maupun yang tidak disengaja.Kesalahan tersebut berkaitan dengan banyak hal sesuai dengan profesi masing masing orang, profesi itu sendiri adalah pekerjaan yang membutuhkan pelatihan dan penguasaan terhadap suatu pengetahuan khusus. Suatu profesi biasanya memiliki asosiasi profesi, kode etik, serta proses sertifikasi dan lisensi yang khusus untuk bidang profesi tersebut. Contoh profesi adalah dokter, pengacara, notaries, jaksa, hakim, akuntan, arsitek, insinyur, dll.

Pekerjaan tidak sama dengan profesi, istilah yang mudah dimengerti oleh masyarakat awam adalah sebuah profesi sudah pasti menjadi sebuah pekerjaan, namun sebuah pekerjaan belum tentu menjadi sebuah profesi.Bahwa untuk dapat disebut sebagai profesi tidaklah mudah, karena memang profesi mempunyai syarat, elemen dan karakter khusus yang tidak dapat dimiliki oleh pekerjaan.Pekerjaan adalah kegiatan fisik dan fikir yang terintegrasi untuk mencapai sebuah tujuan. ${ }^{6}$ Hal inilah yang harus diluruskan di masyarakat, karena hampir semua orang menganggap bahwa pekerjaan dan profesi adalah sama.

Sehubungan dengan semakin meluasnya profesi di Indonesia maka alangkah baiknya kita dalam menjalankan suatu profesi membutuhkan suatu perjanjian asuransi untuk menghindari risiko dari suatu keadaan yang tidak pasti yang bisa timbul karena pihak ketiga, asuransi profesi sendiri adalah suatu jenis asuransi yang bertujuan untuk melindungi aset anda terhadap pihak ketiga yang melakukan tindakan hukum, atau hal. 11

${ }^{6}$ Eman Ramelan, Buku Ajar Etika Profesi. Fakultas Hukum, Universitas Airlangga, 2013,

Pengelola: Program Studi Ilmu Hukum Universitas Muhammadiyah Jember

Penerbit: Universitas Muhammadiyah Jember 
Fairness and Justice: Jurnal Ilmiah Ilmu Hukum

p-ISSN: 1858-0106 e-ISSN: 2502-3926

Volume X Nomor X Bulan, Tahun

http://jurnal.unmuhjember.ac.id/index.php/FA

mengancam untuk mengambil tindakan hukum terhadap Anda atau perusahaan Anda. ${ }^{7}$

\section{Metode Penelitian}

Untuk kebenaran atas suatu karya ilmiah maka di dalam penelitian harus menggunakan sebuah metodologi yang tepat, karena hal tersebut merupakan pedoman yang menentukan akan kualitas hasil yang didapatkan atas suatu penelitian. Berdasar atas pendapat di atas, penelitian tentang perlindungan hukum keterwakilan perempuan dalam pemilihan umum legislatif dalam tata hukum di Indonesia merupakan penelitian yuridis normatif. Penelitian yuridis normatif merupakan penelitian kepustakaan yang menggunakan sumber bahan hukum

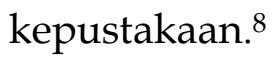

\section{Hasil dan Pembahasan}

\subsection{Karakteristik Perjanjian Asuransi Profesi}

Apabila kita mengetahui penggolongan dari asuransi maka kita bisa mengetahui bahwa perjanjian asuransi profesi disini masuk dalam kategori dari asuransi kerugian karena dalam asuransi ini hanya melakukan prestasi dalam bentuk ganti rugi sepanjang kerugian yang timbul karena adanya suatu peristiwa tidak pasti, dan juga dalam asuransi profesi ini menggunakan sistem "Occurence Basis". Sistem Occurrence Basis ini mempunyai pengertian yaitu sistem dimana polis hanya menjamin klaim/tuntutan berdasarkan kejadian yang timbul/terjadi pada masa periode pertanggungan polis, bahwa klaim tentu harus dilaporkan sesegera mungkin, begitu terjadi suatu peristiwa, klaim, atau adanya tuntutan, somasi, proses klaim, dan sebagainya. Sekali profesidiunduh pada tanggal 28-11-2014

http://www.mitrainsurance.com/index.php/id/produk/asuransi-lainnya/asuransi-

${ }^{8}$ Sidi Alkahfi Setiawan. 2013. Perlindungan Hukum Pekerja Pemegang Saham Di PT Bank Central Asia Tbk. Fakultas Hukum Universitas Jember. Jember. hlm. 18 Pengelola: Program Studi Ilmu Hukum Universitas Muhammadiyah Jember

Penerbit: Universitas Muhammadiyah Jember 
Fairness and Justice: Jurnal Ilmiah Ilmu Hukum

p-ISSN: 1858-0106 e-ISSN: 2502-3926

Volume X Nomor X Bulan, Tahun

http://jurnal.unmuhjember.ac.id/index.php/FA

lagi dalam Polis "Occurrence Basis" waktu terjadinya peristiwa klaim $($ trigger $=$ pemicu $)$ adalah sangat penting dan harus terjadi dalam periode polis, sedangkan kapan pelaporan/tuntutan klaim dilayangkan oleh pihak ketiga dapat saja setelah polis sudah tidak berlaku lagi (expired) dengan catatan tentu tidak melanggar batasan daluwarsa sesuai dengan undang-undang atau peraturan yang berlaku. ${ }^{9}$

Berbeda dari claim made basis yaitu suatu Polis bertanggung jawab terhadap klaim yang dilakukan terhadap tertanggung (claim made) dalamjangka waktupertanggungan. Kejadian yang menimbulkan klaim tersebut dapat terjadi jauh sebelumnya, walaupun seringkalidibatasi dengan tanggal retroaktif (retroactive date).Biasanya digunakan apabila terdapat eksposur laten yang parah, sepertiproduk obat-obatan untuk tanggung gugat produk, dan professional indemnity. ${ }^{10}$ Maka sudah jelaslah dari sini mengapa penulis dalam hal ini setuju dengan tanggapan yang mengatakan bahwa dalam asuransi profesi kita menggunakan system occurrence basic dan bukan menggunakan claim made basic, karena setiap profesi dalam timbul suatu masalah selalu menginginkan agar masalah itu cepat terselesaikan dan tidak menjadi masalah yang berlarut larut, dengan occurance basic ini bisa membantu para profesi dimana apabila ada suatu kejadian tidak pasti maka klaim diajukan pada saat kejadian itu terjadi sehingga bisa dengan cepat terselesaikan dan para profesi bisa kembali menjalankan profesinya.

${ }^{9}$ http://ahliasuransi.com/apa-yang-dimaksud-dengan-"occurrence-basis"/ di akses pada tanggal 4 april 2014.

${ }^{10} \mathrm{http}: / /$ ahliasuransi.com/apa-yang-dimaksud-dengan-"occurrence-basis"/ diakses pada tanggal 24 April 2015

Pengelola: Program Studi Ilmu Hukum Universitas Muhammadiyah Jember

Penerbit: Universitas Muhammadiyah Jember 
Fairness and Justice: Jurnal Ilmiah Ilmu Hukum

p-ISSN: 1858-0106 e-ISSN: 2502-3926

Volume X Nomor X Bulan, Tahun

http://jurnal.unmuhjember.ac.id/index.php/FA

2012

$20 \times x$

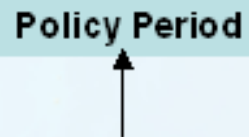

Occurrence
Reporting

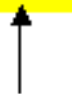

Claim Made

11

Asuransi tanggung gugat profesi merupakan salah satu dari macammacam asuransi yang memberikan perlindungan kepada tertanggung sehubungan dengan tanggung jawabnya menurut hukum kepada orangorang atau pihak-pihak lain berkenaan dengan kehilangan atau terjadi luka badan yang timbul karena kelalaian profesi tertanggung sendiri.Para praktisi ini bisa saja gagal dalam menggunakan keahlian dan kehatihatian di luar ekspektasi dan tanggung jawab normalnya.Jenis polis asuransi ini umumnya dimanfaatkan para dokter dan praktisi medis, para akuntan, para pengacara, para arsitek serta surveyor, agen asuransi serta pialang saham.Dalam tata laksana polis asuransi tanggung gugat profesi, proses sebuah klaim dapat berlangsung dalam waktu yang panjang dan dibagi dalam tiga tahap, yaitu adanya kegagalan dalam melaksanakan profesi, terwujudnya suatu kerugian baik materiil mau pun non-materiil, yang ditutup dengan adanya tuntutan ganti rugi. ${ }^{12}$

Berbicara tentang asuransi profesi maka akan timbul banyak sekali pertanyaan yang akan menghampiri kita, seperti yang sudah dijelaskan diatas tentang mengapa seorang profesional membutuhkan asuransi profesi, akan banyak sekali jawaban yang akan kita terima dimana kaum professional dituntun untuk bekerja professional sesuai dengan profesinya masing-masing. Karena itu segala pelanggaran, kelalaian,

\footnotetext{
${ }^{11}$ https://www.futuready.com/articledetail/index/mengenal-asuransi-tanggung-gugat-profesi di akses pada tanggal 4 April 2014.

${ }^{12}$ Ibid

Pengelola: Program Studi Ilmu Hukum Universitas Muhammadiyah Jember

Penerbit: Universitas Muhammadiyah Jember
} 
Fairness and Justice: Jurnal Ilmiah Ilmu Hukum

p-ISSN: 1858-0106 e-ISSN: 2502-3926

Volume X Nomor X Bulan, Tahun

http://jurnal.unmuhjember.ac.id/index.php/FA

kesalahan atau breach of professional duty dapat menimbulkan kerugian finansial yang sangat besar dan harus dipertanggung jawabkannya.Kesadaran hukum dari masyarakat semakin bertambah pada masa sekarang, sehingga pihak yang mengalami kerugian finansial dapat menuntut ganti rugi dengan menggunakan jalur hukum.Kemungkinan tuntutan ganti rugi dari pihak-pihak yang dirugikan karena kesalahan konsultan atau advis atau service atau pelayanan yang diberikan, dapat mengorbankan harta benda atau asset yang dimiliki Professional.Proses hukum biasanya sangat serius, mahal dan menguras tenaga.Dengan adanya perusahaan asuransi yang memberikan jaminan Professional Indemnity Insurance, maka Professional tidak perlu khawatir dalam menghadapi kemungkinan kesalahan-kesalahan tersebut di atas yang dapat menimbulkan tuntutan ganti rugi yang besar karena akan dijamin oleh asuransi baik jumlah tuntutan ganti rugi yang diklaim maupun biaya proses hukumnya. Lantas apa saja yang dijamin dalam asuransi profesi ini? Ada 2 hal yang akan di jamin dalam asuransi profesi ini antara lain :

1 Tanggung jawab hukum (legal liability) Menjamin kerugian yang dialami pihak ketiga akibat pelanggaran atau kelalaian atau kesalahan dalam menjalankan profesinya;

2 Biaya pengacara atau pengadilan (legal cost)Biaya perkara, biaya pengacara, biaya pengadilan yang harus dikeluarkan akibat tuntutan pihak ketiga tersebut. ${ }^{13}$

Banyak sekali contoh dari profesi yang bisa diasuransikan karena semua pekerjaan juga mengandung risiko, contohnya saja asuransi dokter yang sekarang ini marak sekali di dunia perasuransian. Seperti yang kita ketahui Asuransi tanggung gugat profesi dokter adalah salah satu

\footnotetext{
${ }^{13} \mathrm{http}$ ://asuransitanggunggugat.com/tanya-jawab-seputar-asuransi-profesi-professionalindemnity-insurance/ diakses pada tanggal 21 April 2015 Pengelola: Program Studi Ilmu Hukum Universitas Muhammadiyah Jember Penerbit: Universitas Muhammadiyah Jember
} 
Fairness and Justice: Jurnal Ilmiah Ilmu Hukum

p-ISSN: 1858-0106 e-ISSN: 2502-3926

Volume X Nomor X Bulan, Tahun

http://jurnal.unmuhjember.ac.id/index.php/FA

asuransi yang memberikan jaminan kepada para dokter untuk memperoleh ganti rugi finansial yang dibayarkan kepada pihak ketiga, dalam hal ini pasien, apabila dokter tersebut secara hukum terbukti bertanggung jawab atas kerugian yang diderita oleh pihak ketiga tersebut. Dalam pengertian ini, dokter tersebut bukan hanya mewakili dirinya sendiri tetapi juga bawahannya, pegawai, perawat, atau orang orang yang disuruh/ditunjuk oleh dokter tersebu tuntuk mengurus kepentingannya maupun benda benda atau barang barang yang berada dibawah pengawasan atau penyimpanannya. ${ }^{14}$

Dalam asuransi dokter ini lingkup jaminannya adalah kerugian akibat dari menjalankan profesi medis yang secara hukum bertanggung jawab membayar ganti rugi dari kerugian yang timbul dari cedera badan yang disebabkan oleh kejadian yang terjadi didaerah lingkup jaminan selama masa berlakunya polis.Apabila dikaitkan dengan 2 hal yang maka penanggung hanya bertanggung jawab berdasarkan polis untuk membayarkan ganti rugi ataubiaya klaim yang lebih besar dari ganti rugi dan biaya klaim sebesar jumlah yang menjadi tanggungjawab tertanggung (Insured's Retained Amount) hanya apabila syarat-syarat dalam polis telahdipenuhi.Selain memberikan ganti rugi terhadap pihak ketiga, dalam asuransi dokter ini juga memberikan pendampingan kasus, pembelaan hukum dugaan malparaktek \& kelalaian medik, juga biaya lawyer, peningkatan kesadaran hukum, etik dan safe serta dukungan organisasi profesi terkait. 15

\subsection{Bentuk Pertanggung Jawaban Apabila Terjadi Peristiwa Tidak Pasti Di Dalam Perjanjian Asuransi Profesi}

\footnotetext{
${ }^{14}$ http://asuransiterlengkap.blogspot.com/2013/07/profesi-dokter.html diakses pada tanggal 24 April 2015

${ }^{15}$ http://rezzamartin.blogspot.com/2012/07/asuransi-tanggung-gugat-profesi-dokter.html diakses pada tanggal 24 April 2015 Pengelola: Program Studi Ilmu Hukum Universitas Muhammadiyah Jember Penerbit: Universitas Muhammadiyah Jember
} 
Fairness and Justice: Jurnal Ilmiah Ilmu Hukum

p-ISSN: 1858-0106 e-ISSN: 2502-3926

Volume X Nomor X Bulan, Tahun

http://jurnal.unmuhjember.ac.id/index.php/FA

Satu hal yang cukup pelik dalam asuransi adalah masalah klaim.Disebut pelik, karena dalam klaim yang diajukan oleh tertanggung kepada penanggung, seringkali terjadi perbedaan persepsi antara penanggung dan tertanggung.Adanya perbedaan persepsi ini, tentu saja sulit dipahami oleh tertanggung, sebab yang ada di benak tertanggung, jika ada musibah terhadap objek asuransi tinggal mengajukan klaim. Namun dalam praktik tidaklah segampang yang di bayangkan, mengapa ?karena dari sudut pandang penanggung yang menjadi ajuan adalah polis. Jika tidak sesuai dengan polis, klaim tidak dapat diterima.

Oleh karena tidak ada kesepahaman perihal klaim, lalu muncul sengketa. Dengan demikian, munculnya sengketa dalam asuransi bisa terjadi karena beberapa sebab, seperti yang telah dikemukakan yaitu "Hal yang paling substansial dalam suatu asuransi tentunya adalah klaim dari tertanggung atau pialang asuransi kepada perusahaan asuransi (penanggung) dan selanjutnya pihak penanggung akan mengabulkan atau menolak klaim tersebut. Dalam praktik bisnis asuransi di Indonesia, pihak penanggung menerapkan beberapa prosedur klaim yang berbeda beda, tetapi secara substansial punya kesamaan antara satu perusahaan asuransi dengan perusahaan asuransi lainnya."16

Persengketaan dalam perjanjian asuransi dapat menyangkut segala hal, akan tetapi pada umumnya adalah persengketaan mengenai penyelesaian klaim. Persengketaan klaim umumnya menyangkut 2 hal utama, yaitu pengakuan tanggung jawab atas klaim yang timbul dari penanggung dan besaran klaim yang di tuntut atau dikabulkan.Dalam polis asuransi di Indonesia terdapat berbagai klausul penyelesaian sengketa, baik yang terbatas pada persengketaan mengenai besaran klaim

16 Junimart Girsang, Kejahatan Korporasi Asuransi, Jakarta, Q Communication, 2013 hal Pengelola: Program Studi Ilmu Hukum Universitas Muhammadiyah Jember Penerbit: Universitas Muhammadiyah Jember 
Fairness and Justice: Jurnal Ilmiah Ilmu Hukum

p-ISSN: 1858-0106 e-ISSN: 2502-3926

Volume X Nomor X Bulan, Tahun

http://jurnal.unmuhjember.ac.id/index.php/FA

saja maupun untuk semua perbedaan.Sebagian besar polis telah memuat klausul penyelesaian sengketa melalui arbitrase. ${ }^{17}$

Dari apa yang telah dikemukakan oleh penulis diatas, dapat dipahami bahwa munculnya masalah dalam klaim asuransi atau ditolaknya klaim asuransi, pada dasarnya berpusat pada apa yang dicantumkan dalam polis. Sebagaimana telah dijabarkan sebelumnya, polis sebagai wujud kesepakatan yang dituangkan secara tertulis antara penanggung dan tertanggung perlu ada kesepahaman sejak awal antara penanggung dengan tertanggung tentang : ruang lingkup asuransi, keterlambatan membayar premi. Contoh lain yang menjadi sebab berlarut larutnya pembayaran klaim asuransi yakni, kasus yang sering dibicarakan dalam literature hukum asuransi adalah mengenai istilah "cacat sendiri" sebagaimana yang dijabarkan dalam : Pasal 249 KUHD

"untuk kerusakan atau kerugian yang timbul dari sesuatu cacat kebusukan sendiri atau langsung ditimbulkan dari sifat dan macam barang yang dipertanggungkan sendiri, penanggung tidak bertanggung jawab kecuali dengan tegas diperjanjiakan untuk itu."

Ketentuan pasal 249 KUHD ini berlaku bagi semua asuransi.Hal ini wajar karena pada hakikatnya penaggung hanya menerima pengalihan risiko dari tertanggung atas kerugian yang timbul dari peristiwa yang datang dari luar asuransi. ${ }^{18}$ Apa yang telah dikemukakan oleh para ahli hukum yang mumpuni ini tampaknya ada kaitannya dengan asas itikad baik dalam asuransi, sebagaimana yang tercantum dalam pasal 251 KUHD berikut ini

"setiap keterangan yang keliru atau tidak benar, ataupun setiap tidak memberitahukan hal hal yang diketahui oleh tertanggung, betapapun itikad baik ada pada mereka yang demikian sifatnya, sehingga seandainya, perjanjian itu

${ }^{17}$ A. Junaedy Ganie, Hukum Asuransi Indonesia, Jakarta, Sinar Grafika, 2011, hal 275.

${ }^{18}$ Abdulkadir Muhammad, Op Cit, hal 78

Pengelola: Program Studi Ilmu Hukum Universitas Muhammadiyah Jember

Penerbit: Universitas Muhammadiyah Jember 
Fairness and Justice: Jurnal Ilmiah Ilmu Hukum

p-ISSN: 1858-0106 e-ISSN: 2502-3926

Volume X Nomor X Bulan, Tahun

http://jurnal.unmuhjember.ac.id/index.php/FA

tidak akan ditutup atau tidak ditutup dengan syarat syarat yang sama, mengakibatkan batalnya pertanggungan."

Jika dibaca secara sepintas, apa yang dicantumkan dalam pasal 251 KUHD cukup berat bagi tertanggung, sebab sekalipun beritikad baik tidak dilindungi. Namun, apabila diperhatikan latar belakang lahirnya pasal 251 KUHD tujuannya adalah melindungi penanggung.Maksudnya adalah agar tertanggung memberikan keterangan secara lengkap dan benar mengenai kondisi sesungguhnya tentang objek asuransi.Dengan cara seperti ini, penanggung dapat mengetahui berapa besar risiko yang dihadapinya. Dalam pasal 32 ayat 2 UU No 40 / 2014 yang berbunyi :

"Perusahaan Asuransi, Perusahaan Asuransi Syariah, dan perusahaan pialang asuransi wajib mendapatkan informasi yang cukup mengenai calon Pemegang Polis, Tertanggung, Peserta, atau pihak lain yang terkait dengan penutupan asuransi atau asuransi syariah untuk dapat menerapkan kebljakan anti pencucian uang dan pencegahan pendanaan terorisme."

Telah disebutkan bahwa tertanggung disini harus menyampaikan informasi yang cukup tentang tertanggung kepada penanggung,Oleh karena itu jika diperhatikan secara seksama, apa yang dicantumkan dalam pasal 251 KUHD, cukup memberatkan bagi tertanggung, karena prinsip umum dalam hukum, orang yang beritikad baik dilindungi oleh hukum. Jadi cukup beralasan, bila dikemukakan disini bahwa pasal 251 KUHD terlalu memberikan perlindungan yang berlebih kepada penanggung.

Adanya polis bukan merupakan syarat didalam pemventukan suatu perjanjian asuransi melainkan keharusan adanya polis adalah untuk mengatur pelaksanaan hak dan kewajiban dari masing masing pihak yang timbul dari adanya perjanjian asuransi tersebut.Keharusan adanya polis dalam pasal 255 KUHD tidaklah bersifat mutlak.Adanya kebebasan bagi kedua belah pihak untuk membuat polis berdasarkan perjanjian yang sudah disepakati.Hal ini terbukti dengan adanya suatu perjanjian asuransi Pengelola: Program Studi Ilmu Hukum Universitas Muhammadiyah Jember Penerbit: Universitas Muhammadiyah Jember 
Fairness and Justice: Jurnal Ilmiah Ilmu Hukum

p-ISSN: 1858-0106 e-ISSN: 2502-3926

Volume X Nomor X Bulan, Tahun

http://jurnal.unmuhjember.ac.id/index.php/FA

yang telah mereka bentuk tidak dihubungkan dengan batalnya pada perjanjian asuransi.Meskipun demikian menurut UU ada kewajiban bagi penanggung untuk membuat polis, menandatanganinya dan menyerahkan pada tertanggung (pasal 257 KUHD).Apabila kewajiban ini tidak dilaksanakan oleh penanggung sanksinya penanggung harus bertanggung jawab atas kerugian yang diderita oleh tertanggung sebagai akibat tidak diadakannya polis atau tidak diserahkannya polis/keterlambatannya dalam penyerahan polis.

Dalam suatu polis asuransi profesi ini haruslah polis tersebut bersifat retro aktif, yang artinya selama pihak tertanggung memperpanjang suatu polis maka untuk peristiwa yang akan terjadi menjadi tanggungan dari penanggung, karena kita tidak bisa menebak profesi tersebut apakah aman saja atau tidak, sebagai contoh dari seorang dokter yang menggunakan asuransi profesi ini, karena seorang dokter itu tidak bisa diprediksi peristiwa tidak pastinya maka apabila polis itu tidak bersifat retro aktif maka akan merugikan tertanggung, dokter dalam mengoperasi kanker di tahun 2010 misalnya, karena kanker itu memang penyakit yang sangan rumit timbul lah tumor pada tahun 2014, disini apabila sebuah polis yang tidak bersifat retro aktif maka penanggung tidak mau untuk menanggung kerugian dari tertanggung, berbeda dari polis yang bersifat retro aktif, karena penanggung akan menanggung beban biaya tersebut dengan syarat bahwa dia terus memperpanjang jangka waktu dari polis tersebut.

Polis selain memuat hal hal yang ditentukan oleh undang undang, memuat juag kesepakatan para pihak dalam hubungannyta dengan pelaksanaan hak dan kewajiban. Sehingga setiap polis dalam asuransi pada dasarnya berfungsi untuk:

a. Mengatur pelaksanaan hak dan kewajiban kedua belah pihak;

b. Sebagai dasar tuntutan ganti rugi;

Pengelola: Program Studi Ilmu Hukum Universitas Muhammadiyah Jember

Penerbit: Universitas Muhammadiyah Jember 
Fairness and Justice: Jurnal Ilmiah Ilmu Hukum

p-ISSN: 1858-0106 e-ISSN: 2502-3926

Volume X Nomor X Bulan, Tahun

http://jurnal.unmuhjember.ac.id/index.php/FA

c. Sebagai bukti tertulis atas jaminan penanggung untuk mengganti kerugian yang diderita dan sebagai bukti premi asuransi tertanggung; dan

d. Perhitungan ganti rugi.

Jadi bentuk pertanggung jawaban selain secara materiil juga secara moril dengan memberikan juga bantuan dalam menghadapi adanya tuntutan, setelah adanya suatu laporan secara lisan maupun tertulis dengan diikuti dengan surat tuntutan dari pihak ketiga maka penanggung dapat menyelesaikan klaim dari tertanggung.

\section{Kesimpulan}

Berdasarkan pembahasan dalam bab sebelumnya maka penulis memiliki kesimpulan, antara lain :

1 Karakteristik dari sebuah perjanian asuransi dimana pada dasarnya tidak berbeda jauh dengan perjanjian asuransi pada umunya, tetapi disini apabila kita berbicara mengenai profesi tidak hanya kerugian materiil yang diderita melainkan juga kerugian moril yang berkenaan dengan nama baik dari para professional tersebut, maka dari itu yang membedakan asuransi profesi ini dengan asuransi pada umunya yaitu terletak pada sistemnya dimana pada asuransi kerugian yang lain menggunakan system claim made basicyaitu suatu polis bertanggung jawab terhadap klaim yang dilakukan terhadap tertanggung (claim made) dalamjangka waktupertanggungan. Sedangkan pada asuransi profesi bersistem Occurance Basic yaitu sistem dimana polis hanya menjamin klaim/tuntutan yang timbul/terjadi berdasarkan suatu kejadian pada masa periode pertanggungan polis, bahwa klaim tentu harus dilaporkan sesegera mungkin, begitu terjadi suatu peristiwa, klaim, atau adanya tuntutan, somasi, proses klaim, dan sebagainya. Yang mana system ini dibarengi dengan polis yang bersifat retro aktif Pengelola: Program Studi Ilmu Hukum Universitas Muhammadiyah Jember

Penerbit: Universitas Muhammadiyah Jember 
Fairness and Justice: Jurnal Ilmiah Ilmu Hukum

p-ISSN: 1858-0106 e-ISSN: 2502-3926

Volume X Nomor X Bulan, Tahun

http://jurnal.unmuhjember.ac.id/index.php/FA

jadi apabila terjadi kejadian tidak pasti pada tahun tahun setelah polis berakhir, maka tertanggung tetap bisa memperoleh ganti kerugian dengan syarat memperpanjang masa berlakunya polis.

2 Asuransi tanggung gugat profesi merupakan bentuk dari suatu produk asuransi yang bertujuan untuk memberikan perlindungan kepada para profesi yang berhubungan dengan tanggung jawabnya menurut hukum kepada pihak lainnya berkenaan dengan kehilangan atau terjadi luka badan yang timbul karena kelalaian profesi tertanggung sendiri. Oleh karena itu dalam perusahaan asuransi, dimana berkaitan dengan pemberian ganti rugi telah diketahui bahwa dalam asuransi profesi pemberian ganti rugi bisa melalui 2 bentuk pertanggung jawaban diantaranya, yaitu pemberian ganti rugi secara materiil dimana penanggung menjamin kerugian yang dialami pihak ketiga akibat pelanggaran atau kelalaian atau kesalahan dalam menjalankan profesinya.ataupun pemberian ganti rugi terhadap biaya pengadilan dalam menghadapi tuntutan. 
Fairness and Justice: Jurnal Ilmiah Ilmu Hukum

p-ISSN: 1858-0106 e-ISSN: 2502-3926

Volume X Nomor X Bulan, Tahun

http://jurnal.unmuhjember.ac.id/index.php/FA

\section{Daftar Pusaka}

\section{$\underline{\text { Buku }}$}

Sri Redjeki Hartono. (1985). Asuransi Dan Hukum Asuransi Di Indonesia, Semarang: IKIP Semarang Press

Yan Pramadya Puspa. (1997). Kamus Hukum. Jakarta: Aneka Ilmu Semarang

Sentoso sembiring, (2014). Hukum Asuransi. Jakarta: Nuansa Aulia

Man Suparman Sastrawidjaja. (2014). Aspek aspek hukum asuransi dan surat berharga. Bandung: Alumni

Eman Ramelan. (2013). Buku Ajar Etika Profesi. Surabaya: Fakultas Hukum Universitas Airlangga

Junimart Girsang. (2013). Kejahatan Korporasi Asuransi. Jakarta: Q Communication

A. Junaedy Ganie. (2011). Hukum Asuransi Indonesia. Jakarta: Sinar Grafika

\section{Jurnal}

Zahry Vandawati Chumaida, (2014). Menciptakan Itikad Baik Yang Berkeadilan Dalam Kontrak Asuransi Jiwa 29 Yuridika.

Sidi Alkahfi Setiawan. (2013). Perlindungan Hukum Pekerja Pemegang Saham Di PT Bank Central Asia Tbk. Fakultas Hukum Universitas Jember

\section{Website Resmi}

http://www.mitrainsurance.com/index.php/id/produk/asuransi-

lainnya/asuransi-profesi, diunduh pada tanggal 28-11-2014

http://ahliasuransi.com/apa-yang-dimaksud-dengan-"occurrence-

basis" / di akses pada tanggal 4 april 2014.

http://ahliasuransi.com/apa-yang-dimaksud-dengan-“occurrence-

basis" / diakses pada tanggal 24 April 2015 
Fairness and Justice: Jurnal Ilmiah Ilmu Hukum

p-ISSN: 1858-0106 e-ISSN: 2502-3926

Volume X Nomor X Bulan, Tahun

http://jurnal.unmuhjember.ac.id/index.php/FA

https://www.futuready.com/articledetail/index/mengenal-asuransi-

tanggung-gugat-profesi di akses pada tanggal 4 April 2014.

http://asuransitanggunggugat.com/tanya-jawab-seputar-asuransi-

profesi-professional-indemnity-insurance/ diakses pada tanggal 21

April 2015

http://asuransiterlengkap.blogspot.com/2013/07/profesi-dokter.html

diakses pada tanggal 24 April 2015

http://rezzamartin.blogspot.com/2012/07/asuransi-tanggung-gugat-

profesi-dokter.html diakses pada tanggal 24 April 2015 